\title{
УДК-32
}

DOI: 10.17072/2218-1067-2019-1-68-82

\section{‘BILBAO ON THE KAMA’? THE PERM CULTURAL PROJECT AND ITS CRITICS (PART 1)}

\author{
Douglas Rogers \\ Yale University
}

\begin{abstract}
The following text is the first part of the Chapter 8 of Douglas Rogers's book The Depths of Russia: Oil, Power, and Culture after Socialism (Cornell University Press, 2015). The second part will be published in the next issue of the journal. The review of the book was published in the journal in 2017, No. 2. It is a prominent study of the 'Perm cultural project', one of the most important events in regional politics over the 2000s. That is why we publish this text with the kind permission of the author and the publisher. Earlier chapters of the book are dedicated to the Soviet-era history of oil in the Perm region, the privatization of the 1990s, and Lukoil's social and cultural projects.
\end{abstract}

Keywords: cultural policy; art; oil; business and politics.

"Do you know that there is a Cultural Revolution happening in Perm?" The up-beat, customer-servicefriendly voice belonged to the teenager minding the museum shop at the Perm Museum of Contemporary Art. It was March 2011, and I had come for the opening of an exhibition of avant-garde video art featuring the Moscow-based collective AES+F's Feast of Trimalchio and a number of other installations. Smiling brightly, she directed me to the newest additions: stylized designs featuring Perm's regional symbol—a bear —and a new raft of notebooks, tote bags, and other items featuring "I Love Perm" designs. On the shelves behind these souvenirs stood an impressive array of beautiful and expensive art books for sale, including a growing collection of catalogs from the museum's own exhibits. The shop was tucked into the corner of a vast exhibition space, spread out over two floors in what was once Perm's River Station Hall, originally built in 1940 to serve boat traffic on the Kama River and, in 2008, refurbished and reopened as a contemporary art museum. I had been to the museum several times before, but the practiced jollity of that historically freighted line about cultural revolution brought me up short. It seemed as incongruous as the video art itself. AES+F's reinterpretation of the story of Trimalchio (a former Roman slave turned thrower of lavish feasts who appears in the middle chapters of Petronius's Satyricon) was a set of large, digital animations and stills depicting scenes of overthe-top luxury at a twenty-first-century resort hotel. The excesses it depicted were especially striking installed inside the soaring spaces of the Perm River Station's Stalin Empire-style architecture. It is unlikely that the production of such jarring moments was part of that young woman's training, but the idea that contemporary art can produce unsettling moments was at the very heart of the museum's mission to spur individual and collective transformations in Perm. Indeed, the Perms Museum of Contemporary Art, known as PERMM, was the epicenter of a series of high-profile cultural projects and conflicts associated with Governor Chirkunov's campaign to have Perm officially declared a European Capital of Culture in 2016.

\section{Art and Oil}

Culturally focused corporate social responsibility projects located at and near sites of oil extraction —of the sort discussed in chapter 6-are a comparatively recent phenomenon worldwide. A much longer-running set of ties between the global oil complex and the production and consumption of culture has lain elsewhere,

(C) Rogers D., 2019 
closer to the urban sites where oil wealth has tended to accumulate. These ties include corporate sponsorship of major urban cultural centers (art museums, theaters, opera houses, and so on); executive philanthropy and trusteeship at this same group of institutions; and the avid participation of both oil companies and individuals with oil-derived fortunes in the collection of works of art. "The major enduring legacy of the wealth of [dynastic families]," write George Marcus and Peter Dobkin Hall in their ethnography of American inheritance and philanthropy, "is Culture itself" (Hall, 1992: 9). A particularly dense set of such ties, for instance, has long woven together New York City's Museum of Modern Artand several generations of the Rockefeller family (see Rockefeller Archive Center 2011, 28-29), and corporate involvement in the global art world has only increased since the 1980s (Wu, 2002).

Relationships of this sort began to emerge rapidly in the mid-2000s boom in Russia, when new fortunes had been largely consolidated, oligarchs were looking to establish long-term legacies, and Russian corporations were responding to critiques from all quarters. Major Russian oil and gas companies sponsored all manner of exhibits, renovations, and performances at Russia's most respected cultural institutions. Big Lukoil, to give but one example, established a standing relationship with the State Tretyakov Gallery in Moscow in late 2007, sponsoring a number of exhibits and restorations and, in 2008, an international traveling exhibit titled "Magical Landscapes." These were also heady days for private collectors on the Moscow art scene, with around $\$ 68$ million spent at auction for Russian contemporary art over the course of 2007 and 2008 (Hewitt, 2010: 77). ${ }^{1}$ Some of Russia's new rich went further still, not only expanding their own collections as a way to reinvest their millions but also helping to build new exhibit spaces, such as the popular art4.ru and Vinzavod galleries (both opened in Moscow in 2007), sponsoring favored artists through personal grants and subsidies, and even curating exhibits and shows (the most-cited example is Dasha Zhukova, partner of Roman Abramovich).

These kinds of practices and relationships began to emerge, on a much more modest scale, as new oil wealth coursed through Perm. In addition to the grant- based competitions for social and cultural project funding in which district-level cultural organizations participated, Lukoil-Perm (together with the Perm Financial-Productive Group [PFPG]) served as general sponsors of both the Perm Opera and Ballet Theater and the Perm Drama Theater. Perm's first independent art gallery, Maris-Art, opened in 2001, and specialized in works by artists from the Perm region, past and present. There was no shortage of art to display or visitors for exhibitions in the gallery's small space in central Perm, across the street from the heavily trafficked Perm State Art Gallery, but sales were another story. Maris-Art initially served a very small number of independent collectors - too few, in the early years, to pay the rent. "Thank God," its director told me, "that in those early years an understanding grew up in Perm that there is such a thing as a corporate gift." The PFPG, LukoilPerm, and Permneftorgsintez were her chief clients in the early 2000s, and Maris-Art regularly advised all three on gifts for others in the business world and, just as frequently, filled commissions to pro- vide artwork for corporate offices. A number of Lukoil-Perm executives also took a personal interest in the emerging art world, in at least two cases providing personal contributions to help the gallery publish catalogs and other books. The gallery maintained a warm relationship with Andrei and Nadezhda Agishev, who over the course of the 2000s became perhaps the most widely known independent supporters and collectors of art in the Perm region. (Andrei Agishev, recall, was a PFPG veteran who had also spent time at the head of PermRegion-Gaz and went from there to a position in the Perm Legislative Assembly; his wife Nadezhda chaired the board of directors at the Ermak Investment Company and, after a period of private collecting, founded the independent New Collection Foundation for the Support of Cultural Projects, which focused specifically on art.)

The global financial crisis and associated plummeting oil prices-from $\$ 147$ per barrel in July 2008 to a low of just $\$ 32$ per barrel later that same year-had an immediate impact on Russia's art scene. By 2009, global auction sales of Russian contemporary art dropped to a mere $\$ 6.4$ million-a small fraction of the previous years' totals (Hewitt, 2010: 78). By 2010, the once enormously successful art4.ru gallery in Moscow was open only one day a week, its sponsorship money having nearly dried up and ticket sales an insufficient replacement for a decimated operating budget. It therefore seems counterintuitive that the Perm Museum of

\footnotetext{
${ }^{1}$ Degot and Diaconov provide useful insiders' snapshots of these years (Degot, 2010; Diaconov, 2011; see also Chukhrov, 2011).
} 
Contemporary Art and the cheerful Cultural Revolution it was in- tended to spark originated in precisely these crisis years. This apparent anomaly, however, was in fact at the very center of ongoing transformations of corporation, state, and cultural politics in the post-Soviet Perm region. Accounting for this anomaly adds a final example to the ways in which the Perm region was constituted as an oil-producing region within Russian state and corporate fields after socialism. Even as Perm's Cultural Revolution was designed to chart a path out of hydrocarbon dependency, I will suggest, the debates and conflicts that surrounded it served largely to extend and entrench the centrality of oil to regional political, economic, social, and cultural sensibilities. The material properties, spatialities, representations, and regional transformations of oil were again highly significant.

\section{Oleg Chirkunov's Team}

Vladimir Putin appointed Iurii Trutnev, whose efforts to transform Perm into Russia's Capital of Civil Society helped set the tone for regional state-corporate relationships in the critical early years of the 2000s, to the position of minister of natural resources of the Russian Federation in 2004. Trutnev, along with a number of his key deputies, promptly decamped for Moscow. In Trutnev's place, Putin installed Oleg Chirkunov, first as acting governor in 2004, then as officially appointed governor in the Perm region in 2005. (The post of governor switched from elected official to designee of the president of the Russian Federation in 2004 as part of the Putin administration's efforts to reconsolidate federal power.) Although Chirkunov's initial background was in the Soviet security services (he graduated from the KGB's higher school in 1985 and served, by most accounts, until 1993), he was more well known in the Perm region as a member of Trutnev's former management team at Eks Limited, a sprawling company that had made a fortune as a supplier of consumer goods since the late 1990s - in part based on the European connections Chirkunov had made during a stint as Russia's trade representative in Switzerland. The first years of Chirkunov's term as governor coincided with massive influxes of oil- and gas-based revenues into the Perm region and Russia as a whole, and Chirkunov's former associates at Eks Limited were well positioned to take advantage of the boom in consumption, especially from their new Sem'ia chain of department stores, which rapidly spread through Perm and other major cities in the region. Chirkunov's wife and children remained in Switzerland during his entire term as governor and had dual citizenship; these ties and frequent visits to Western Europe were generally assumed to be motivating, at least in part, his European Capital of Culture campaign and his interest in contemporary art.

Although certainly no overt or persistent critic of the Putin administration, Chirkunov was far from a simple executor of plans hatched in Moscow. He was not, for instance - and never became - a member of Putin's United Russia Party. "He is, basically, a trader," I was told more than once. "What he knows how to do more than anything else," said one acquaintance, "is to buy and sell things." "He's a Thatcherite," said another. In the classification of Russian political/economic styles of the time, Chirkunov was a self-identified and proud liberal, a close enough approximation to what is often meant by the term "neoliberal" in the West. He believed fervently in the power of markets and entrepreneurship, and was skeptical of any significant role for government in economic or social spheres. In the introduction to a collection of his own writings and reflections published in 2012 with the support of the Russian Liberal Mission Foundation, Chirkunov wrote that, in the twenty years of reform since 1991,

there occurred in the public consciousness and in the consciousness of the elite a refusal of a competitive, market model in favor of stability, planned economic development, and, connected to both, the inevitable centralization of power. This book is an attempt to propose an alternative to the strengthening of the state in all spheres of life. (Chirkunov, 2012:24)

As governor, Chirkunov championed tax cuts for regional businesses through the 24-20 Program and did everything he could to slow and, eventually, stop the regional administration's social and cultural project grants that had been so central to his predecessor's administration, believing them to be an unhelpful form of 
government subsidy. Instead, he traveled the region promoting the virtues of entrepreneurship as a solution to local social problems.

One of the central tensions running along the Moscow-Perm axis in the years of Chirkunov's governorship (2004-12) was, then, a generally increasing central- ization of the federal state apparatus in Moscow coupled with an avidly market- oriented and anticentralization (yet federally appointed) governor. The boom years of the mid-2000s masked some of this tension for a time, as recirculated oil wealth coursed through the region and the country and meant that social problems could be temporarily solved with infusions of cash. But, as Chirkunov noted in the same 2009 speech in which he declared Perm's Capital of Culture ambitions, all was no longer well. Between 1998 and 2007, employment in the drilling and mining sector had fallen by 25 percent as Lukoil-Perm and its extractive industry companions restructured their labor forces. The entire sector (including both oil and mining) employed only twenty thousand people in 2009-1 percent of the population of the Perm region. Whatever money Lukoil-Perm and its fellow natural-resource-exploiting corporations were generating, they were not providing jobs for the region even in the boom years of the mid-2000s, and the decline in regional tax revenues beginning in 2008 was exposing problems. Indeed, people were still moving out of both Perm and the Perm region at a steady rate, unemployment was increasing, and many social services continued to be unreliable. In the face of these circumstances, the prospect of further declines in tax receipts from Lukoil-Perm, and increasing demands from the population, what was a market-oriented governor to do?

By his own account, Chirkunov's discovery of culture as a possible answer began in 2007. That was the year in which he named Sergei Gordeev as one of the Perm region's two senators-delegates to the Russian Federation Council (the Up- per Chamber of the Russian Legislative Branch). Gordeev, a Moscow-based billionaire who had made his fortune by founding a real estate business in 1995 and then riding it through the astounding boom of the early and mid-2000s, had no previous relationship to the Perm region. His entry into Russian political life had come during a period of service as a senator from the Ust-Orda Buryat Autonomous Republic (also not his home). His appointment from both areas points to a common strategy among Russian provincial regions at the time: recruiting rich and politically connected patrons based in Moscow as senators in the hopes of diverting personal and federal funds to projects in the regions that they represented.

Only in his mid-thirties at the time he began his term as a senator from Perm, Gordeev had developed an interest in urban architecture and, in particular, in rescuing and preserving avant-garde architecture in Moscow-much of which was threatened by decades of neglect and the tendency of most developers, with the support of powerful Moscow mayor Iurii Luzhkov, to level whatever stood in the way of building the next hulking business center or shopping mall. Although professional devotees of architecture greeted Gordeev's interest in the avant-garde and urban design with considerable skepticism at first, he had won over many of his critics through his dogged determination to transform the Melnikov House, near the very center of Moscow, into a museum. In 2007, Gordeev helped to fund and participated in The Lost Vanguard: Russian Modernist Architecture, 1922-32 at the Museum of Modern Art in New York, and his foundation, Russian Avantgarde, supported collections and the publication of a series of books on major avant-garde artists and movements. Press releases and published retrospective accounts indicate that the idea to establish a Museum of Contemporary Art in Perm emerged fairly early in the collaboration between Governor Chirkunov and Senator Gordeev. Both were interested in making a high-profile move to trans- form Perm on the model of the European postindustrial cities they were familiar with, Bilbao and Glasgow among them, and they agreed that this long-term project should begin with a contemporary art museum.

The network that set in motion what would eventually be called the Perm Cultural Project thus emerged, on the one hand, out of the new and booming consumption side of the Perm region economy represented by Chirkunov (as opposed to Soviet industry, from which Gennadii Igumenov had hailed, and the Communist Party's Komsomol wing, which had been Iurii Trutnev's primary background and power base) and, on the other hand, out of the Moscow-based nexus of fantastic, hydrocarbon-charged real estate wealth and avant-garde art represented by Gordeev. To help execute their project of transforming Perm, the duo turned to Marat Gel'man, a Moscow-based collector and gallerist at the very center of the contemporary 
art scene. Gel'man was the founder of the first private art gallery in Moscow (the Marat Gel'man gallery, opened in 1990) and had recently begun dabbling in politics as well, consulting on a number of political campaigns beginning in the mid-1990s through his Foundation for Effective Politics.

The Moscow art world was not without its intrigues and scandals - and Gel'man was rarely far from them - but bigger threats to Gel'man and his colleagues' operations in Moscow were the instabilities that came with their close ties to Russia's hydrocarbon boom. Real estate prices in Moscow, for instance, were becoming prohibitive for gallery and exhibition space, let alone for beginning artists to live. Gel'man related to me in an interview that real estate in Moscow had become a like "gold bars," with everyone "investing their oil money in it and just waiting for the price to go up." It was hard, he said, to maintain a gallery in those conditions, at least without ever-increasing sales and prices for art. Indeed, Gel'man was fond of telling newspaper reporters that 80 percent of his customers at the Marat Gel'man Gallery in 1996-2008 had moved abroad, and that they were replaced not by other wealthy private businesspeople who might dabble in expensive contemporary art but by wealthy members of the Russian state apparatus who were interested in hiding their wealth rather than being conspicuous about their fortunes and sophistication by participating in the Russian corner of the global art market. ${ }^{1}$ In these conditions, Governor Chirkunov and Senator Gordeev's invitation to Gel'man presented an opportunity that seemed to be both obvious and insane: a move to the provinces, where, with few exceptions, there had yet to be much interest in contemporary art, where property prices were lower by orders of magnitude, where artists themselves could more easily make a living, and where new regional elites might be interested in following Moscow elites into the art market, both as a form of investment and as an arena of distinction.

At Chirkunov's urging, Gordeev's ambitions for Perm had never been small. His first thought was apparently to open a branch of the Guggenheim in Perm, and negotiations got as far as site visits by the leadership of the Guggenheim Foundation. Ultimately, however, he and Chirkunov settled on a different plan ("the Guggenheim is the day before yesterday," Gordeev told the magazine SNOB in 2010): opening the Perm Museum of Contemporary Art, with Marat Gel'man as director. ${ }^{2}$ Gordeev supplied personal funds of around $\$ 400,000$ to renovate Perm's River Station Hall for this purpose, and the space was reregistered as a stateowned museum in short order. ${ }^{3}$ Gordeev described his decision to a local magazine:

The prevailing idea in the world is that a museum of contemporary art is a multiplex where networked products are rolled out. For example, the exhibition of a big artist's work travels around the world, very stylish, glamorous, and global. People come and look. And then the exhibition is packed up and travels to another city. So it's a circuit, like film distribution. This conception is supported by the Guggenheim Foundation - it's the leader in this movement. And the positions in this approach are only getting stronger. So Vilnius has invited the Guggenheim museum to build a museum there, there's already been a competition to choose the architect... Baku is doing more or less the same thing. And also Astana, Abu-Dhabi. Many oil economies are going according to this script. And this network trend, I'll call it that, will be very influential, and probably dominating in the coming years. But I don't think that's the path that Perm needs. We need to create a museum that will show the world something that is to be found nowhere else ... something mod-ern, uniquely unusual, and at the same time, ours. "Ours" without the patriotism, with pride in our artists, but without beating our chests. ${ }^{4}$

The Perm Museum of Contemporary Art was, then, another attempt to put Perm and its region on the map - this time on the global map of cities where accumulated oil wealth was being transformed into culture.

\footnotetext{
${ }^{1}$ Masha Charnay, “Marat Guelman: ‘Things Can Work Differently,'Russia behind the Headlines, May 17, 2012.

${ }^{2}$ Maksim Kotin, "Permskaia Anomalia," SNOB, June 2010, 84.

${ }^{3}$ Although Perm was home to a quite well-known classical art museum, the Perm State Art Gallery (Permskaia Khudozhestvennaia Galleria), contemporary and avant-garde art had no previous institutional presence in the city's museums, universities, or artists' unions. As the plans for PERMM moved ahead, Perm also hosted a major summer festival, Perm-A Territory of Culture, that showcased contemporary art and artists in the summer of 2009.

${ }^{4}$ Vladislav Gorin, “Prodiuser Gordeev," Kompan'on Magazine, November 7-11, 2008.
} 
The something "uniquely unusual" that Gordeev envisioned would carry the same name as PERMM's inaugural exhibit, curated by MaratGel'man: Russkoe Bednoe, or Russian Povera— the Poor Arts of Russia.

\section{Russian Povera}

The Russian Povera exhibit assembled the work of some three dozen Russian artists and art collectives whose work featured found objects, trash, and ruins. Vladimir Arkhipov contributed photographs and exhibits of socialist and post- socialist objects put to unexpected use: a rusting bed repurposed as a footbridge, a road sign attached to a long pole and used as a shovel. Some contributions were direct, "poor" commentaries on well-known art elsewhere in the world: Vladimir Anzelm's Skull recalled Damian Hirst's famous For the Love of God - except that it was encrusted in coal rather than diamonds. The Blue Noses' contribution, Kitchen Supremacism, commented on Malevich with a photograph of geometrical shapes made of assorted types of salami arranged on the chipped paint of an old table. And there were many others: sculptures of welded wire obtained from fences; a spaceship composed of glued-together cigarettes and cigarette boxes; and a rendering of the familiar Pravda masthead in rubber cut from automobile tires. Ol'ga and Aleksandr Florenskii's Skeletons, a series of sculptures, cobbled found objects into resemblances of elephants, snakes, fish, and other animals. Their Map of the Central Part of the City of Perm, commissioned especially for the exhibit, was made of materials found in Perm's garbage dumps and in the basement of the River Station Hall. Its neatly labeled pieces included a rusted car muffler representing the Kama River and scraps of wood and metal serving as streets and familiar buildings. The goal of reimagining Perm through contemporary art was, perhaps, most explicitly on display in this piece, and it became part of PERMM's permanent collection, frequently exhibited as part of one or another aspect of the larger Perm Cultural Project.

Many of the works exhibited in Russian Povera had previous lives on the glitzy contemporary art scene in Moscow, where they were generally not understood to be in the Povera style at all. It was their grouping together in a provincial city that enabled Marat Gel'man and his collaborators to cast this exhibition as illustrative of a movement in the Russian art world. ${ }^{1}$ Indeed, Russian Povera had a distinctly and intentionally grubby aesthetic, one that matched the lightly restored River Station Hall in which it took place. An exhibition catalog featured extensive inter- views with many of the artists, asking them questions about their engagements with the material qualities of found objects in light of the exhibition's organizing theme. Aleksandr Brodskii, one of the more well-known artists featured, pointed out that Povera-style art was just about the only art remaining that could be produced without a sponsor and a budget, and that while he himself was now in the position to embark on some of these big-budget art works, it was still possible and useful to cultivate a poor aesthetic. Such art should be considered every bit the equal of sponsored, big-budget art (PERMM, 2008: 26-27).

In his introduction to the catalog, Marat Gel'man expounded on the exhibit's effort to highlight a theme in contemporary Russian art that had, to that point, gone underappreciated. Russian Povera, he wrote,

has an important subtext-its naturalness. It is much closer to nature than art that is rich, glossy, and built on technologies. The very material of Russian Povera returns us to naturalness . . . wealth has migrated to other spheres; it has been co-opted, consumed, has turned into advertising, design, magazine beauty, what you will, having lost the ability to be art. (PERMM, 2008: 24).

Povera art refused the separation of art and life, he went on, as well as any grounding in theories of what art really is, in favor of exploring a wider range of possibilities and processes, with all kinds of materials and experiments. Noted philosopher and critic Boris Groys added his own take, suggesting that "in losing their glamorousness, these things gain their own histories... the viewer's attention shifts from the object itself to its genealogy and its practical use" (PERMM, 2008: 26). In the version of the catalog that accompanied Russian Povera to the third Moscow Biennial in 2009, Gel'man elaborated further on what he saw as the differences

\footnotetext{
${ }^{1}$ I thank Molly Brunson and Bella Grigoriyan for their promptings on this point.
} 
between Russian Povera and its antecedents. The Italian Arte Povera movement of the 1960s, he suggested, was born of a conscious, principled, ascetic rejection of the consumer practices of postwar Italy, of the homogenization of beauty in the commodity form. Russian Povera, by contrast, arose in the late 1980s, 1990s, and early 2000s from the actual lack of opportunities, materials, and sponsorship that was enjoyed by Western artists. It was the child, that is, of post-Soviet transformation. Russian Povera's artists, he wrote, made art out of cardboard and found objects because that is what they could afford to work with; only over time had they learned to consciously deploy these materials for a range of purposes, among them the principled critique made by the Italian Arte Povera movement. PERMM's mission, wrote Gel'man, should be to become the world center for the collection of Arte Povera of all kinds - especially but not exclusively the Russian variant (PERMM, 2009: 2-4).

Artists and art critics would doubtless have much more to say about the works exhibited at PERMM. I adopt a somewhat different perspective, that of the study of "art worlds," which understands the study of art to extend to lectures and seminars, institutions such as state and corporate agencies, other domains of cultural production such as literature or festivals, and even everyday conversations about art (Becker, 1982; Marcus and Myers, 1995; Winegar, 2006). From this broad perspective, several aspects of Russian Povera are significant. Despite its omnipresence on the Perm region's cultural scene at the time, Lukoil-Perm was not a direct sponsor of either PERMM or the Russian Povera exhibit. The project was quite assertively driven by Chirkunov's team and funded through a combination of Moscow-based private donations (chiefly Gordeev's) and the Perm regional budget. It was therefore a break with the practices of Governor Trutnev's administration, which had so closely tied regional oil to regional cultural sponsorship. Indeed, PERMM represented both a new level of intervention in the cultural field by the Perm regional state apparatus and, at the same time, an etatization at the regional level of what had been, in Moscow, largely a private-sector affair — an issue to which I return.

Despite Lukoil-Perm's refusal to participate officially, there were some striking similarities between the cultural projects that the company continued to sponsor in the Perm region's oil-producing districts and Russian Povera. Both, to begin with, relied on powerful notions of authenticity. In Lukoil-Perm's cultural projects, this was an authenticity to be attained through a turn to deep historical, ethnic, and national roots (and, correspondingly, away from contemporary inequalities and exclusions). In Russian Povera, this authenticity was to be attained by leaving behind the world of commodity images. Boris Groys's comments, quoted above, went on to suggest that Russian Povera's artwork had the potential to escape the loss of aura that Walter Benjamin famously argued comes with mechanical reproduction (Benjamin, [1936] 1968). Both claims to authenticity rested on a similar kind of oil-inflected spatiotemporal shift, accomplished at different scales. Authentic culture could be best found through movement to more provincial areas: from Perm to outlying oil-producing districts of the Perm region in the case of Lukoil- Perm's cultural projects, from glamorous Moscow to provincial yet oil-rich Perm in the case of PERMM. Just as the quest to reclaim national and ethnic identities sponsored by Lukoil-Perm played out at some distance from Perm, that is, it was really only in the poorer and grittier provinces that one could truly locate a museum of Russian Povera as Gel'man and Gordeev imagined it. (A review of the exhibit in the Moscow newspaper Kommersant noted obligingly that, in order to get out to see Russian Povera in Perm, one had to "splash through Russian filth.") ${ }^{1}$ Russian Povera even traded occasionally in the semiotics of depth and authenticity that were so prominent in Lukoil-Perm's historical and cultural projects, with the curators writing in the exhibit's English-language press release that,

The basis of the exhibition is work by artists who use the simplest, "poor" materials. This approach reveals and demonstrates all of the qualities of contemporary Russian art—an art that is authentic, deep, an art that goes away from surface beauty towards a real miracle. ${ }^{2}$

\footnotetext{
1 "Chtoby popast' na Russkoe Bednoe, nuzhno proshlepat' po russkomu griaznomu." The phrases "Russian Povera" and "Russian filth"-Russkoe bednoe and russkoe griaznoe - form an evocative poetic pair that links movement to the provinces with increasing poverty and dirtiness. Roman Dolzhanskii, "Permi podali bednost," Kommersant, September 25, 2008.

${ }^{2}$ See www.bednoe.ru/eng.
} 
Whether located at the sites of extraction or accumulation, these cultural projects also took place with international audiences in mind, with the goal of put- ting both Russia and the Perm region on the map. The frequently heard claim that Lukoil-Perm sponsored local folk arts were well known "in Russia and around the world" (see chapter 6) was not so very different from Gordeev's and Gel'man's ambitions for Russian contemporary art at PERMM. To be sure, Lukoil-Perm's international audience was an investment marketplace increasingly concerned with corporate transparency and citizenship, demanding corporate social responsibility programs as a condition of full participation in capital markets and the oil trade, while PERMM's audience was an international art world actively debating the place and value of Russian art on the global stage. But the questions that were being debated and worked out in the Perm region were quite similar in both the oil and art worlds: What characterized Russian products—whether oil or works of art—in global contexts? Were they distinctive in some way, and who would be the arbiters of that distinctiveness-Western institutions (international capital markets for oil companies, a global museum elite for artists)? If the global circuit of energy specialists was curious about how red directors were meshing with new financiers in the ongoing transformation of the post-Soviet oil industry, then a similar question could be asked of the booming contemporary art world, with its established artists from the Soviet period working in new circumstances and its many young and largely unrecognized artists. PERMM, in sum, brought questions about the global audiences for Russian art and Russian oil into new and close proximity in the provincial Perm region (cf. Adams on cultural spectacles in Uzbekistan (Adams, 2010)).

There were similarities, finally, between the kinds of relations - among humans and between things and humans - contemplated at Russian Povera and in Lukoil-Perm's sponsorship of folk handicraft production and sale. Both sought to grapple with the involution and impoverishment of the 1990s by putting homemade or found items on display and into monetized circulation in new ways. Making due with materials that were at hand, refashioning them into things that were usable and profitable, and even basing a cultural revitalization program on the results were all features shared by Lukoil-Perm's cultural CSR programs in the early 2000s and the Russian Povera exhibit in the late 2000s. "We exist in a society of global castoffs," wrote Petr Belyi, another artist whose work was included,

They are presupposed by a global economy... We live in a post-Soviet, postindustrial society with a ruined heavy industry, which was so hard to create and fell apart so insanely easily... As an artist, I feel comfortable at a ruined factory, next to the abandoned [excavator] bucket... the exploration of materials, the rifling through of cast-offs, trips to trash heaps, are a constant need. (PERMM, 2008: 79).

His words echo those of the Lukoil-Perm's Connections with Society employee who summarized the company's proposal to the impoverished and unemployed residents of oil-producing districts: "Sit home, sew, make some pottery, and maybe you can make a living of some sort" (see chapter 6).

This was, however, a similarity that supporters and artists connected with Russian Povera were only willing to take so far, and they responded to my queries on this topic by deploying a version of the commonly made hierarchical distinction between handicrafts and art (compare, for instance, Winegar, 2006: 63). Folk handicrafts and Povera art, one interlocutor told me, might look superficially similar in their transformations of everyday items in the contexts of post-Soviet economic involution, but folk handicrafts, it was important to remember, "have no conception of themselves as art." One of the contributors to the Russian Povera exhibit, Vladimir Arkhipov, addressed this question in his catalog interview in a similar way, speaking of his works featuring everyday items:

[In my art] I preserve the authorship of people who make sincere things. They create while paying no mind to aesthetics or quality; their things exist in an everyday environment and are not perceived as works of art... For its maker, a handcrafted thing is, on the one hand, a solution of a domestic problem; on the other, it's creativity, but he does not understand that. (PERMM, 2008: 28; emphasis added) 
This last point is debatable as a matter of principle: inasmuch as many folk artisans (and even nonartisan everyday improvisers, as I learned in my previous fieldwork on a former Soviet state farm) are highly attuned to their own creativity. But the perception that the artists exhibited at PERMM knew and projected something about creativity that others did not was absolutely central to the entire Perm Cultural Project. It was precisely this point - the possibilities of unrecognized, untapped creativity in the ways in which the Perm region's residents trans- formed their material surroundings - that the backers and sponsors of PERMM hoped to inculcate through a cultural revolution spreading outward from a museum of contemporary art. It was here, in this cultural creativity, that new entrepreneurs would be born and new paths to postindustrial, post-hydrocarbon economic development opened. In his own introduction to the exhibit catalog, Senator Gordeev elaborated on his vision of contemporary art as the "new engine" of Perm's economy. "The factories that served as the motors of Permian civilization have not disappeared," he wrote, but

they have also grown "tired" of pulling the city along all by themselves. They need help. Perm's new contemporary art museum, he said, is called upon to turn a giant layer of Permian subconscious, of hidden ambitions, into a project, a point on the map, a destination. (PERMM, 2008: 22).

In 2009, Oleg Chirkunov began a high-profile effort to ensure that the trans- formative project he had set in motion would not stop at the walls of the River Station Hall. He announced that the defining project of the remainder of his governorship would be an effort to have Perm displace Saint Petersburg as Russia's unofficial cultural capital. Less than a year later, on March 1, 2010, he revised this goal upward to having Perm officially designated a European Capital of Culture in 2016. In his speech announcing this target, Chirkunov argued that Perm would become a place where "creative people will live- and that means that many different sectors will develop differently — not just culture." There would be a new "economy of the intellect, where we will create not with our hands but with our heads." Every problem that needed to be solved in the region was in large or small part ("and probably in large part") a factor in regional cultural development. Anticipating one line of critique, he concluded that: "It's not cities like Paris, or London, or Moscow that aim for these projects. It is cities that need a breakthrough, that, thanks to that project and the gathering of resources at a specific point in a specific place, break through and become great cities." Perm, he contended, needed a breakthrough as much as any small European city. If Istanbul, not even located in a European Union member state, could be a European Capital of Culture, then what was stopping Perm?

Chirkunov's subsequent budgets in the Perm region reflected these priorities. Spending on cultural projects rose nearly tenfold between 2008 and 2012, and of the 567 million rubles allocated to cultural programming in 2012, 540 million, or 95 percent, was dedicated in one way or another to the European Capital of Culture campaign. ${ }^{1}$ In an earlier era of global political economy, political leaders often sought to reinvest soaring oil revenues in the development of local industry. Fernando Coronil's treatment of the political economy of oil in mid-twentieth century Venezuela, for instance, follows attempts to "sow the oil" by building a domestic auto industry to compete with Detroit and foster domestic Venezuelan agricultural production (Coronil, 1997: 237-85). Chirkunov, Gordeev, and their associates picked a development project for a different era of global capitalism, one that that privileged creativity, culture, consumption, and entrepreneurship over industry, labor, and social sector spending. Among other things, they said, it was much cheaper and more realistic to develop culture than to attempt to rehabilitate industry.

\section{The Perm Project: Creative Life in a Cultural Capital}

Post-Soviet art worlds have been instructively theorized in a variety of ways: as a domain in which new understandings of - and borders between - religious and secular are hashed out (Bernstein, 2014); as vehicles for the legitimation of new kinds of power or authority (Bazylevych, 2010); and as sites of specifically

\footnotetext{
1 “95\% kraeovogo biudzheta Minkulta poidet na proekt Perm—Kul'turnaia Stolitsa," Argumenty i Fakty, February 14, 2012. See www.perm.aif.ru/society/details/603031 (accessed August 17, 2014).
} 
postsocialist combinations of state power and commercial value (Nauruzbayeva, 2011). PERMM and its broader cultural revolution point us in still another direction: to contemporary art as a technique of transformation, an arena where it com- ingled with other domains of culture - from theater to festivals to film - and with the transformative agendas of state agencies, corporations, and others. In her masterful ethnography of Egyptian artists and their interlocutors in the late 1990s and 2000s, for instance, Jessica Winegar explores ways in which "cultural policy ... is part of modern strategies of governance and the move to neoliberalism" (Winegar, 2006: 142). She goes on to argue that Egyptian "national arts policy was the cultural accompaniment to neoliberalism, stressing international progress, flexibility, and democratic openness as made manifest in 'avantgarde' art" (Winegar, 2006; see also Miller and Yúdice, 2002). ${ }^{1}$ In the Perm region as in Egypt, state-led cultural policy played out in apparently contradictory ways: increased state participation in the cultural sphere, for instance, proceeded in tandem with ongoing privatization in other spheres (even in the cultural sphere itself in oil-producing districts, as Lukoil-Perm's cultural CSR projects demonstrated).

As it began to extend outside the walls of PERMM, the Perm Cultural Project was led by another addition to Governor Chirkunov's team: Boris Mil'gram. Mil'gram was a theater director who, although born in Odessa, had studied in Perm in the 1970s, eventually receiving an advanced degree in chemical sciences and participating in an active and popular student theater. (Oleg Chirkunov was a student in Perm at the same time, several people pointed out to me.) Mil'gram trained as a theater director in Moscow in the late 1980s, and went on to gain sig- nificant renown both in Moscow at the Mossovet Theater (In the 1990s) and subsequently back in Perm, beginning in 2004, as head of the Perm Drama Theater. Chirkunov appointed him minister of culture and mass communications in 2008, as plans for PERMM were getting under way, and promoted him again in 2010 to the post of vice-premier of the Perm regional government, a position he held until Chirkunov's resignation in the spring of 2012.

"I came to the Ministry [of Culture] to put on a play," Mil'gram told the newspaper Gazeta.ru. ${ }^{2}$ If there was an overall script for that play, it was a 122-page manifesto titled The Perm Project: A Conception of Cultural Policy for the Perm Region, released in 2010 (Zelentsova, 2010). ${ }^{3}$ The lengthy document, which Mil'gram had a central role in composing, presented itself as the views and work of a collection of project managers, experts, and economists in the field of culture and cultural politics. The Perm Project elaborates in much greater detail the view of culture as engine of postindustrial development that Gordeev and Chirkunov had set out. Culture, in the understanding of the authors, is primarily a zone for the "creative self-expression and self-realization of every person"; this "creative potential," in their view, "will become the main factor in the development of all economic subjects" (Zelentsova, 2010: 1). The basic lexicon of The Perm Project will be familiar to those well versed in the language of creative cities. Culture in the Perm region was to be "open and dynamic," "self-organized," and would be based not on sector-wide programs but on "clusters" bringing together "innovative companies, firms, and creative groups" to serve social and cultural needs. Projects in the field of culture would unfold quickly, creating jobs and attracting tourists far faster than any attempt to rebuild the region's industrial or defense sector. The Perm Project was conceived of as a way of making new kinds of people - creative, free, independent - and a new kind of society. "We rely on the resources of culture, art, and heritage," the coauthors wrote. "But that is not even the most important. The primary resource of the project is the creativity and creative potential of society itself" (Zelentsova, 2010: 45). In the straightforward terms in which Mil'gram put it to me in an interview, the project as a whole aimed for "the formation of a mechanism for the self-realization of the person." Or, as Marat Gel'man told me, culture should be understood as impacting everything having to do with the life of a city, and to invest in culture was therefore to drive all other sectors, from large to small business. "An entrepreneur and an artist," he said,

\footnotetext{
1 As Winegar is well aware, links between the creativity associated with avant-garde art and national and international transformations of political economy are not limited to the neoliberal era; see, for instance, Guilbaut's (1983) study of American abstract impressionism in the early Cold War. I thank Brinton Ahlin for his prompts and references on this point.

${ }^{2}$ Vadim Nesterov, "Ia prishel v ministry sdelat' spektakl'," Gazeta.ru, September 22, 2010.

${ }^{3}$ See also Abashev 2009 for an earlier collaborative effort between Chirkunov's team and members of the local intelligentsia.
} 
it's the same mentality... [one that] makes you want something. It's just that for the artist, you want to express something, for the entrepreneur, that's not as important . . . and so, we are beginning to produce, for now in small quantities, these new kinds of people... This is how I am considering art, as an instrument for solving problems in the territory as a whole.

Such were the transformations contemplated under the rubric of Cultural Revolution in Perm-new entrants into the crowded field of technologies of the self in the second postsocialist decade (see, for instance, Matza, 2009; Zigon, 2011).

Although frequent aspirational comparisons for Perm as cultural hub were postindustrial cities of Europe and the United States (Glasgow, Pittsburgh, Bilbao, and others), at least as common were comparative references to Russia's own hydrocarbon sector. In a public address in 2009, for instance, Mil'gram sought to shake the default assumption that cultural potential paled in comparison to the revenues, prestige, and influence of the oil and gas industry:

The expense for the development of culture is nothing. The financial valuation of the heritage of Picasso is higher than the capitalization of Gazprom. The biggest taxpayer in England is not the president of BP but the author of Harry Potter. Financial turnover in the film industry is comparable to that of oil, and the cultural heritage of Italy, France, or Spain makes them richer than the biggest hydrocarbon deposits would.

In The Perm Project and other visions for the future of Perm, oil clearly belongs to the industrial past, not the postindustrial present and future. Whereas natural resources like oil are by definition scarce, culture is portrayed as endlessly creative, everywhere, and inexhaustible. Or, as Mil'gram put it to me in one of our conversations, "There is no cultural sector, because culture can't be controlled. There is the infrastructure of culture: departments, organizations, creative unions. But that is only a part of culture, because culture is a whole, it is everything. It is everything, especially in a cultural capital." Indeed, as a resource with endless potential - after initial private and state investment — culture was the ideal fix for the declining oil reserves in the region and the specter of the resource curse that had begun to worry Russian economists and policymakers. What better sector to diversify into than one that could be framed as not beset by problems of scarcity at all? In the 1990s Perm region, dreams of unimaginable wealth, possibilities of unfettered growth, and hopes of putting Perm on the map gathered around pyramid schemes and rags-to-riches privatization tales. In the early and mid-2000s, these dreams shifted to the realm of oil wealth. By the end of the decade, the plan was for culture to take up that role: dreams of ever-expanding oil wealth would be replaced by the endless potential of human cultural creativity. Chirkunov's signature line on this topic was, simply, "A City Should Have a Dream."

As I have noted, Lukoil-Perm was not a sponsor of the Russian Povera exhibit or of PERMM, although, of course, the steady stream of tax revenue from the company underwrote a significant part of the state budget allocations for these and all other state cultural initiatives. The company continued to distance itself from Chirkunov's Perm Cultural Project in official and general terms, although it did chip in some significant sponsorship funding when the Perm Cultural Project began to include city-wide public festivals. ${ }^{1}$ "They have their projects," Mil'gram told me, that take place out in the districts, where they invest in cultural projects, where they work on historical memory, historical cities. They do this on their own level, and we don't interfere much... It's called parallel processes, and we only welcome that. We never want to tell them "Do this, or don't do that." We will find other resources to do our work here [on the Perm Cultural Project].

\footnotetext{
${ }^{1}$ In 2006, however, the company was an ardent support of Perm's status as Cultural Capital of the Volga Federal District-a project that unfolded under the auspices of the social and cultural project competitions central to regional development plans at the time; see Nikolai Trukhonin, “Skoro Gorod Izmenitsia!” Permskaia Neft' 21 (195), October 2006.
} 
Indeed, despite its advocacy of flexible and mobile state-corporate-culture projects as central to life in a cultural capital, The Perm Project does not mention Lukoil-Perm at all (although big Lukoil in Moscow does come up as a suggested funder of cultural projects of national significance). For its part, Lukoil-Perm kept its primary focus on oil-producing districts and the depths of cultural and national traditions.

The Perm Project and those behind it remained quiet on their opinions about the ways in which Lukoil-Perm's social and cultural projects were clearly connected to boosting the company's own image, but they were often direct and unsparing in their criticism of those in Russian government on this score, including the federal Ministry of Culture - who, they believed, continued to see culture as a domain of mere heritage preservation and/or state ideological work (Zelentsova, 2010: 21). Importantly, in their view, the Perm Cultural Project was not an instance of a state using the cultural sphere as a domain of legitimation in the guise of state tutelage (gosudarstvennaia opeka), or shoring up the legitimacy of the state, as classic Soviet cultural work attempted to. "Culture in the Soviet Union was a very strong tool," said Mil'gram in one of his many public addresses on the matter,

it was an ideological instrument for the restraint (uderzhanie) of the country. An ideological influence (vozdeistve). And inasmuch as it was a tool, it was well financed and it was a territory of status, that is, people who worked in culture had some status.

It was true that the state picked what kind of art or theater you could and could not engage in, and that artists suffered for this, he went on, but the status of culture in the Soviet Union was no doubt higher than it was in the post-Soviet period. Culture could regain that high status again, he said, not by returning to being the ideological partner of a powerful state, but by becoming its own re- source, its own locomotive for economic growth. Indeed, it is clear from the first pages of The Perm Project that Chirkunov and his collaborators' goal was to make culture a topic of conversation among economists, businesspeople, and politicians in addition to its traditional practitioners and managers. ${ }^{1}$

The Perm Cultural Project was, then, envisioned just as much as a transformation of the state as of individuals and communities, and its architects were anxious to restructure the state cultural bureaucracy, which they saw as built around outdated expectations and understandings of culture. Much of The Perm Project described changes that the organizers deemed necessary to create the larger-scale transformations they envisioned: the legal status of cultural institutions needed to be changed in order to accommodate a range of flexible and evolving collabo- rations among state agencies, businesses, and artists of various sorts; officials in significant positions in the cultural affairs hierarchy needed to be concerned with fundraising, marketing, and branding; budget forecasts needed ways to calculate the effectiveness of cultural work; and the entire process needed to be streamlined, made more flexible and adaptive, and professionalized. The language of business plans, in short, needed to find its way more firmly into the Ministry of Culture itself. Culture as a budget item, moreover, needed to be moved out of its current location in the social sphere of the state budget. Funding for the arts and culture, Boris Mil'gram emphasized in a 2009 address, had long been connected with Soviet ideology; when that ideology collapsed, culture took a place next to other categories and other groups that expected help from the state. Artists, museums, and theaters were lumped into the same overall category as pensioners, hospitals, and disabled people in the state's "social territory." Gel'man told me that, "Traditionally, in Russia, and not only in Russia, culture was in the same place as beg- gars at the church gate, hospitals, elderly people receiving pensions ... in other words, in the formation of any budget, it was in the social sector."

And there, he said, it always loses, because, of course, a hospital will be repaired before a museum is built. So long as culture was funded in accordance with the remainder principle (ostatochnyi printsip), in

\footnotetext{
${ }^{1}$ One of the ways in which they accomplished this was by making the cultural capital project a regular theme of the annual Perm Economic Forum, at which regional elites across all sectors gathered and met with outside guests. The opening of the Russian Povera exhibit was timed to coincide with the 2008 Perm Economic Forum, and culture played a prominent role in the 2009 and 2010 iterations. The Perm Culture Project was then made into the overarching theme of the 2011 Forum, at which a parade of featured experts from around the world advised Perm's leading politicians and corporate executives on matters of city branding, cultural revival, urban renewal, and the creative industries.
} 
which it received only what was left over after all other budget items were funded, the Perm Cultural Project would founder. "We are saying," Marat Gel'man went on, "that culture in the contemporary world plays a different role — an infrastructural role."

The Perm Project was, finally, a deeply regional document, insistent on the ways in which cultural projects of the sort it envisioned must come from the provinces and not from the federal center. The broader Perm Cultural Project, in other words, set out to challenge existing patterns of state cultural production in Russia by rethinking their spatiality. "For three hundred years," Gel'man told me, "culture has been concentrated in the center"- in Moscow and Saint Petersburg. He and his collaborators were actively revising that organization of space, he went on, allowing the provinces to develop their own initiatives and advertise their own cultural distinctiveness, and to do so on their own terms. This was not, he hastened to add, a critique of Putin-era Russia. It was a critique of much of the sweep of Russian history: whatever the period, whatever the politics, whatever the regime, the field of culture had been dominated by the centrality of Moscow and Saint Petersburg. "We're breaking prejudices [against the provinces], said Gel'man, "Everywhere I go, in other [provincial] cities, people feel themselves to be revolutionaries. They tell me, 'we want to do what Perm has done.'"

In Governor Chirkunov's estimation, this remaking of cultural space was not only a challenge to the federal center but also, in fact, a promising strategy in the never-ending battle to beat out other Russian regions for federal funds. By staking out the terrain of cultural capital, he hoped to position Perm to receive federal investments of the same sort - if perhaps not at the same scale - that had been earmarked for Saint Petersburg's three-hundredth anniversary in 2003; Kazan's thousandth anniversary in 2005, and the reconstruction of So- chi for the 2014 Olympics. If, he argued persistently, Perm were to become the best place to make artistic careers, both out of city residents and new arrivals, and if it had the best new art museum, the best experimental theater, the most renowned festival life in the summer months, then federal aid for infrastructural projects such as renovating the train station, airport, or local roads would follow in short order. ${ }^{1}$

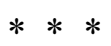

At the center of the cultural field at the end of the 2000s in the Perm region was, then, a not uncommon paradox: massive state-funded cultural production, recognized by all as such, that was nonetheless cast as a way to diminish the power of the regional state apparatus and to direct the source of creativity, transformation, and entrepreneurship away from the state itself. In the 1990s, the active work of creating selves and state agencies in the wake of socialism was quintessentially that of Western aid agencies, nongovernmental organizations, and other sorts of advisers (see, in a very large literature, Mandel, 2002b; Rivkin-Fish, 2005; Hemment, 2007). In the early 2000s in the Perm region, as I showed in earlier chapters, much of this task was taken up by the oil industry and state agencies working in close concert, in good part on the terrain of culture, through state- corporate grant competitions and the spread of the project movement. By the late 2000s, as Lukoil-Perm and the regional state apparatus grew further apart, both continued to pursue this cultural effort on parallel, in many ways similar, and highly spatialized tracks - the oil company through its ongoing cultural CSR work in the region's oil-producing districts, and the state apparatus through the increasingly omnipresent Perm Cultural Project focused largely in Perm itself.

\footnotetext{
${ }^{1}$ On links between region or identity branding and the quest for investment, see also (Comaroff and Comaroff,2009).
} 


\section{References}

Абашев, В.В. (ред.) (2009) Город Пермь: смысловые структуры и культурные практики. Пермь. [Abashev, V.V. (ed.) (2009) Perm City: semantic structures and cultural practices [Gorod Perm': smyslovye struktury i kul'turnye praktiki]. Perm: Perm State University Publ. (In Russ.)].

Зеленцова, Е. (ред.) (2010) Пермский проект: Концепция культурной политики Пермского края. Пермь. [Zelentsova, E. (ed.) (2010) The Perm project: Concept of cultural policy of the Perm region [Permskii proekt: Kontseptsiya kul'turnoi politiki Permskogo kraya]. Perm. (In Russ.)].

Пермский музей современного искусства «ПЕРММ». «Русское бедное». Каталог (2008). Пермь: ПЕРММ. [Perm Museum of Contemporary Art (PERMM). 'Russian Povera'. Catalogue [Permskii musei sovremennogo iskusstva "PERMM". "Russkoe bednoe". Katalog] (2008). Perm: PERMM Publ. (In Russ.)].

Пермский музей современного искусства «ПЕРММ». «Русское бедное». Московская биеннале современного искусства (2009). Москва: Немецкая фабрика печати. [Perm Museum of Contemporary Art (PERMM). 'Russian Povera'. Moscow Biennale of Contemporary Art [Permskii musei sovremennogo iskusstva "PERMM". "Russkoe bednoe". Moskovskaya biennale sovremennogo iskusstva] (2009). Moscow: Nemetskaya Fabrika Pechati Publ. (In Russ.)].

Чиркунов, О. (2012) Государство и конкуренция. Москва: Новое литературное обозрение. [Chirkunov, O. (2012) State and competition [Gosudarstvo i konkurentsiya]. Moscow: Novoe literaturnoe obozrenie Publ. (In Russ.)].

Adams, L. (2010) The Spectacular State: Culture and National Identity in Uzbekistan. Durham, NC: Duke University Press.

Bazylevych, M. (2010) 'Public Images, Political Art, and Gendered Spaces: Construction of Gendered Space in Socialist and PostSocialist Ukraine', Journal of Contemporary Anthropology, 1 (1), pp. 2-19.

Becker, H. (1982) Art Worlds. Berkeley: University of California Press.
Benjamin, W. (1968) 'The Work of Art in the Age of Mechanical Reproduction' in Arendt, H. (ed.) Illuminations: Essays and Reflections, pp. 217-252. New York: Schocken.

Bernstein, A. (2014) 'Caution, Religion!: Iconoclasm, Secularism, and Ways of Seeing in Post- Soviet Art Wars', Public Culture, 26 (3), pp. 419-448.

Chukrov, K. (2011) 'Art after Primitive Accumulation: Or, on the Putin- Medvedev Cultural Politics', Afterall: A Journal of Art, Context, and Enquiry, 26, pp. 127-136.

Comaroff, J.L., Comaroff, J. (2009) Ethnicity, Inc. Chicago: University of Chicago Press.

Coronil, F. (1997) The Magical State: Nature, Money, and Modernity in Venezuela. Chicago: University of Chicago Press.

Degot, E. (2010) 'A New Order', Artforum International, 49 (3), pp. 107-110.

Diaconov, V. (2011) 'The Russian Question', Artforum International, 49 (6), pp. 52-54.

Guilbaut, S. (1983) How New York Stole the Idea of Modern Art. Chicago: University of Chicago Press.

Hemment, J. (2007) Empowering Women in Russia: Activism, Aid, and NGOs. Bloomington: Indiana University Press.

Hewitt, S. (2010) 'What Makes a Market? The State of Russian Contemporary Art', Art and Auction, 34 (1), pp. 74-79.

Mandel, R. (2002b) 'A Marshall Plan of the Mind: The Political Economy of a Kazakh Soap Opera'. In: Ginsburg, F., Abu- Lughod, L., Larkin, B. (eds.) Media Worlds: Anthropology on New Terrain. Berkeley: University of California Press, pp. 211-228.

Marcus, G., Hall, P. (1992) Lives in Trust: The Fortunes of Dynastic Families in Late Twentieth-Century America. Boulder, CO: Westview Press.

Marcus, G., Myers, F. (1995) 'The Traffic in Art and Culture: An Introduction' in Marcus, G.E., Myers, F.R. (eds.) The Traffic in Culture: Refiguring Art and Anthropology. Berkeley: University of California Press, pp. 1-51.

Matza, T. (2009) 'Moscow's Echo: Technologies of the Self, Publics, and Politics on the Russian Talk Show', Cultural Anthropology, 24 (3), pp. 489-522. 
Miller, T., Yúdice, G. (2002) Cultural Policy. Thousand Oaks, CA: Sage.

Nauruzbayeva, Z. (2011) 'Portraiture and Proximity: 'Official' Artists and the Stateization of the Market in Post- Soviet Kazakhstan', Ethnos, 76 (3), pp. 375-397.

Rivkin-Fish, M. (2005) Women's Health in PostSoviet Russia: The Politics of Intervention. Bloomington: Indiana University Press.
Winegar, J. (2006) Creative Reckonings: The Politics of Art and Culture in Contemporary Egypt. Palo Alto, CA: Stanford University Press.

Wu, Chin-Tau. (2002) Privatising Culture: Corporate Art Intervention since the 1980s. New York: Verso.

Zigon, J. (2011) HIV is God's Blessing: Rehabilitating Morality in Neoliberal Russia. Berkeley: University of California Press.

\title{
Информация об авторе
}

Роджерс Дуглас - PhD (University of Michigan), профессор антропологии Йельского университета (США). E-mail: douglas.rogers@yale.edu (ORCID: 0000-0002-6607-8404. ResearchID: V-7570-2018).

Статья принята к печати: 15.12.2018

\section{«БИЛЬБАО НА КАМЕ»? ПЕРМСКИЙ КУЛЬТУРНЫЙ ПРОЕКТ И ЕГО КРИТИКИ (ЧАСТЬ 1)}

\author{
Д. Роджерс \\ Йельский университет (США)
}

\begin{abstract}
Аннотация
Предлагаемый текст - первая часть гл. 8 книги Дугласа Роджерса «The Depths of Russia: Oil, Power, and Culture after Socialism» (Cornell University Press, 2015). Вторая часть будет опубликована в следующем номере журнала. Рецензия на книгу была опубликована в журнале в 2017 г., №2. Книга Дугласа Роджерса - замечательное исследование «Пермского культурного проекта», одного из самых значительных событий в региональной политике в 2000-е гг. Поэтому мы публикуем этот текст с любезного разрешения автора и издательства. Ранние главы книги посвящены истории нефти советской эпохи в Пермском крае, приватизации 1990-х гг, и социально-культурным проектам Лукойла в 2000-х гг.
\end{abstract}

Ключевые слова: культурная политика; искусство; нефть; бизнес и политика. 